\title{
PENGARUH KUALITAS PELAYANAN TERHADAP LOYALITAS NASABAH DENGAN KEPUASAN SEBAGAI VARIABEL MEDIASI PADA LPD
}

\author{
I W. Widnyana ${ }^{1}$, I N. Suamanayasa ${ }^{2}$ \\ 1,2Jurusan Manajemen, Universitas Pendidikan Ganesha, Singaraja \\ e-mail: iwayanwidnyana18@undiksha.ac.id ${ }^{1}$, nengah.suarmanayasa@undiksha.ac.id²
}

\begin{abstract}
Abstrak
Penelitian ini bermaksud untuk menguji pengaruh: (1) kualitas pelayanan pada kepuasan nasabah, (2) kualitas pelayanan pada loyalitas nasabah, (3) kepuasan nasabah pada loyalitas nasabah, dan (4) kepuasan nasabah dalam memediasi pengaruh kualitas pelayanan pada loyalitas nasabah di LPD Desa Adat Ularan. Desain penelitian yang digunakan dalam penelitian ini adalah penelitian kuantitatif kausal. Subjek dalam penelitian ini adalah nasabah tabungan di LPD Desa Adat Ularan dan objek dalam penelitian ini adalah kualitas pelayanan, kepuasan nasabah, dan loyalitas nasabah. Sampel dalam penelitian ini berjumlah 100 responden. Data diambil melalui pencatatan dokumen dan metode kuesioner, serta dianalisis dengan path analysis. Hasil penelitian menunjukkan bahwa: (1) kualitas pelayanan berdampak positif dan signifikan pada kepuasan nasabah, (2) kualitas pelayanan berdampak positif dan signifikan pada loyalitas nasabah, (3) kepuasan nasabah berdampak positif dan signifikan pada loyalitas nasabah, dan (4) kepuasan nasabah memediasi parsial pengaruh kualitas pelayanan pada loyalitas nasabah di LPD Desa Adat Ularan.
\end{abstract}

Kata kunci : kualitas pelayanan, kepuasan, loyalitas nasabah

\begin{abstract}
This research is intended to examine the influences of (1) service quality towards customers' satisfaction, (2) service quality towards custormers' loyalty, (3) customers' satisfaction towards customers' loyalty, and (4) customers' satisfaction in mediating service quality towards customers' loyalty in LPD Desa Adat Ularan. The research design of this research used casual quantitative research. The subject of this research is the customers of LPD Desa Adat Ularan, and the object of this research is the quality of services, customers' satisfaction, and customers' loyalty. The sample of this research involved 100 respondents. Therefore, the data of this research were collected through document recording, questionnaire design, and analyzed by path analysis. The results of this research showed that: (1) service quality has a positive and significant effect towards customers' satisfaction, (2) service quality has a positive and significant effect towards customers' loyalty, (3) customers' satisfaction has a positive and significant effect towards customers' loyalty, and (4) customers' satisfaction partialy mediate the effect of services quality towards customers' loyalty in LPD Desa Adat Ularan.
\end{abstract}

Keywords: service quality, satisfaction, and customers' loyalty

\section{Pendahuluan}

Pembangunan daerah pedesaan menjadi sangat krusial dan tidak bisa terpisahkan dari pembangunan nasional. Dalam rangka meningkatkan kesejahteraan rakyat, pemerintah pun mulai memberikan bantuan kredit kepada kegiatan usaha di pedesaan. Hal inilah yang mendasari Pemprov Bali menerbitkan SK Gubernur Nomor 972 tahun 1984 tentang Pendirian Lembaga Perkreditan Desa (LPD) Provinsi Bali dengan tujuan utama demi kepentingan layanan masyarakat, khususnya pada sektor ekonomi desa guna menunjang kehidupan masyarakat desa. Landasan hukum yang lebih mendalam mengenai pendirian LPD selanjutnya mulai dirintis dan keberadaannya ditegaskan melalui Peraturan Daerah Provinsi Bali Nomor 3 Tahun 2017. LPD merupakan pranata keuangan milik desa pakraman yang berkedudukan di wilayah desa pakraman (Pasal 1 Perda No. 3 Provinsi Bali Tahun 2017). Sejak awal berdiri, perkembangan jumlah LPD di Bali mengalami peningkatan yang sangat signifikan. Hingga tahun 2019, total terdapat sejumlah 1.433 LPD yang ada di Bali. Sembiring 
(2013) menyatakan bahwa perkembangan LPD disebabkan karena masyarakat desa percaya pada LPD untuk menabung dananya, dan didistribusikan kembali dalam bentuk credit yang diserahkan kepada anggota masyarakat sebagai nasabah.

Salah satu kabupaten di Bali dengan jumlah LPD yang merata di setiap kecamatannya adalah Buleleng. Tercatat hingga tahun 2019 terdapat 169 LPD dan 817 tenaga kerja yang terlibat dalam LPD di Kabupaten Buleleng. Total pengelolaan asetnya mencapai $\mathrm{Rp}$ 2.569.735.825.000 dan total laba yang diperoleh sebesar Rp 58.624.492.000 (Pemerintah Kabupaten Buleleng, 2019).Total sebanyak 169 LPD yang tersebar di 9 kecamatan Kabupaten Buleleng, Kecamatan Seririt memiliki jumlah LPD terbanyak yang mencapai 25 LPD. Artinya hampir sebesar $15 \%$ dari total LPD di Kabupaten Buleleng berada di Kecamatan Seririt. Salah satu LPD di Kecamatan Seririt yang memiliki pengelolaan aset yang besar adalah LPD Desa Adat Ularan. LPD Desa Adat Ularan adalah pranata keuangan dibidang perkreditan yang dibangun di Desa Adat Ularan, Kecamatan Seririt, Buleleng, Bali dengan tujuan utama sebagai pondasi keberlangsungan hidup masyarakat Desa Adat Ularan melalui aktivitas perniagaan masyarakat yang berkesinambungan.

Jumlah nasabah untuk tetap menggunakan jasa LPD mengalami fluktuasi selama periode bulan Mei-September 2020. Dimana dari bulan Mei hingga Juli terjadi penurunan jumlah nasabah sebesar 4,5\% (17 orang), bulan Agustus mengalami peningkatan sebesar $1,10 \%$ (4 orang), dan bulan September kembali mengalami penurunan sebesar $2,19 \%$ (8 orang). Jumlah nasabah LPD Desa Adat Ularan yang mengalami fluktuasi menandakan loyalitas nasabah terhadap LPD juga mulai berkurang, karena kebiasaan transaksi, kesetiaan, dan komitmen nasabah untuk tetap menggunakan jasa LPD Desa Adat Ularan mengalami inkonsistensi. Hal ini sejalan dengan ungkapan dari Selnes (1993), yang mengemukakan bahwa indikator loyalitas nasabah adalah konsistensi nasabah untuk melakukan kebiasaan transaksi, pembelian ulang, rekomendasi, dan komitmen dari nasabah. Kotler (2006) dalam Permana dan Nurcahya (2014) juga menyatakan bahwa indikator loyalitas terdiri atas tetap setia, tidak berpindah ke merek lain, menyarankan kepada orang lain, pilihan utama dalam bertransaksi, dan menerangkan hal-hal yang positif kepada masyarakat lain. Walaupun perkembangan aset yang dimiliki dan tingkat keuntungan (laba) yang didapat LPD Desa Adat Ularan cukup besar. Namun, melihat kondisi jumlah nasabah yang mengalami fluktuasi, tentunya hal ini akan menjadi suatu permasalahan bagi operasional LPD kedepannya.

Ketidakpuasan nasabah harus diminimalisir oleh LPD Desa Adat Ularan dengan mengupayakan peningkatan pelayanan setiap harinya. Kepuasan nasabah timbul ketika pelayanan yang diberikan sesuai dengan harapannya, dengan kepuasan tersebut akan mampu menimbulkan sifat loyal dibenak nasabah. Kepuasan nasabah memediasi dampak kualitas pelayanan pada loyalitas nasabah (Caruana dalam Iskandar dan Wijaksana, 2015). Hasil riset oleh Putri dan Suasana (2017) menegaskan bahwa kepuasan secara signifikan memediasi variabel kualitas layanan pada loyalitas nasabah di PT. BPD Bali Cabang Renon. Berdasarkan riset yang dilakukan Minh dan Huu (2016) pada Sektor Perbankan Ritel Vietnam, bahwa dari hasil analisis tersebut memperlihatkan bahwa anteseden yang paling berperan pada pengaruh kualitas layanan dan kepuasan nasabah adalah kesetiaan nasabah. Riset lain yang dilakukan oleh Purnomo dan Widowati (2019) pada Bank Kanca Wonosari juga menegaskan bahwa hubungan antara kualitas layanan pada loyalitas nasabah dapat dimediasi oleh kepuasan secara signifikan. Namun, riset lainnya yang dikemukakan oleh Octavia (2016) pada Bank Index Kantor Cabang Lampung menyimpulkan bahwa kepuasan nasabah tidak berpengaruh dalam memediasi kualitas pelayanan dan loyalitas nasabah. Serta riset Iskandar (2012) pada BPR Bkk Boyolali Kota menyatakan bahwa kepuasan dan kepercayaan nasabah belum dapat berperan menjadi variabel mediasi pada dampak kualitas pelayanan terhadap loyalitas nasabah.

Tolak ukur kepuasan nasabah adalah tentang bagaimana kualitas pelayanan yang diberikan oleh bank. Parasuraman et al. (1988) menyatakan ketika pelayanan yang diberikan mampu melebihi harapan nasabah maka nasabah tersebut merasa puas. Baik atau tidaknya persepsi nasabah mengenai pelayanan bank tergantung antara kesesuaian dan keinginan pelayanan yang didapatnya. Hubungan kualitas pelayanan terhadap kepuasan nasabah 
disampaikan oleh Kotler dan Keller (2009) yang menjelaskan bahwa nasabah yang mempersepsikan kualitas layanan yang baik maka akan merasa puas. Sehingga diharapkan kualitas pelayanan nasabah meningkat, dengan harapan nasabah akan semakin puas terhadap LPD. Hasil riset oleh Putri dan Suasana (2017) pada PT. BPD Bali Cabang Renon menyatakan kualitas layanan berdampak signifikan pada kepuasan nasabah. Hasil riset Trisnayani dan Setiawan (2014) pada BPD Bali Kantor Cabang Pembantu Kamboja Denpasar juga menyimpulkan bahwa kualitas layanan berdampak positif dan signifikan pada kepuasan nasabah. Namun, riset lainnya yang dilakukan oleh Dibyantoro (2012) pada PT Bank Tabungan Negara (Persero) Cabang Palembang menunjukkan bahwa dalam uji t terdapat tiga (3) dimensi kualitas pelayanan yang tidak berdampak pada kepuasan nasabah yaitu reliability, responssiveness, dan assurance. Serta, riset oleh Sarker (2012) pada Bank Komersial Swasta di Bangladesh menyimpulkan bahwa dalam pengujian dimensi kualitas pelayanan didapat dimensi responsif dan bukti fisik tidak berdampak pada kepuasan nasabah.

Kualitas pelayanan mempunyai hubungan yang kuat dan dapat menciptakan loyalitas nasabah terhadap bank yang memberikan pelayanan yang menyenangkan (Tjiptono, 2012). Menurut Durianto et al., (2001), kualitas pelayanan adalah pandangan nasabah tentang keunggulan suatu produk (jasa) yang LPD berikan. Salah satu poin penting guna mempertahankan nasabah adalah dengan melakukan pelayanan yang baik. Tentunya nasabah akan beralih ketempat lain apabila pelayanan yang diberikan tidak maksimal (Astuti dalam Wijaya dan Mandala, 2018). Karena beraneka ragamnya superioritas LPD tersebut, maka terciptalah kualitas pelayanan masyarakat terhadap LPD. Sehingga diharapkan kualitas pelayanan meningkat, dengan harapan nasabah akan semakin loyal terhadap LPD. Hasil riset oleh Putri dan Suasana (2017) pada PT. BPD Bali Cabang Renon menyatakan kualitas pelayanan secara signifikan berdampak pada loyalitas nasabah. Hasil riset Trisnayani dan Setiawan (2014) pada BPD Bali Kantor Cabang Pembantu Kamboja Denpasar menyimpulkan bahwa kualitas layanan juga berdampak positif dan signifikan pada loyalitas nasabah. Namun, riset lainnya yang dilakukan oleh Octavia (2016) pada Bank Index Kantor Cabang Lampung menyatakan bahwa kualitas pelayanan tidak berdampak secara signifikan pada loyalitas nasabah.

Kepuasan nasabah dalam memakai jasa LPD merupakan suatu proses rinci sehingga dipengaruhi berbagai faktor dalam menciptakan loyalitas nasabah. Keberadaan LPD dikatakan sangat membantu karena dalam penyaluran kreditnya LPD lebih mengedepankan masyarakat dengan keadaan ekonomi menengah kebawah sebagai modal usaha, bunga kredit yang rendah, sistem bunga yang tidak terlalu tinggi, dapat dipermudah melalui Kipem (Kartu Identitas Penduduk Musiman) dan pemberian jaminan oleh kepala desa, serta proses pengambilannya yang cepat (Kurniasari, 2007). Sehingga diharapkan kepuasan nasabah meningkat, dengan harapan nasabah akan semakin loyal terhadap LPD. Riset yang dilakukan oleh Purnomo dan Widowati (2019) pada Bank Kanca Wonosari menyatakan kepuasan nasabah berdampak positif dan signifikan pada loyalitas nasabah. Selain itu, menurut riset Zakiy dan Azzahroh (2017) pada Bank Syariah di Indonesia juga menunjukkan hasil yang sama bahwa kepuasan nasabah berdampak positif dan signifikan terhadap loyalitas nasabah. Namun, riset lainnya yang dilakukan oleh Yaqin dan Ilfitriah (2014) pada E-banking di Surabaya menyatakan bahwa kepuasan nasabah berdampak positif tidak signifikan terhadap loyalitas nasabah, yang berarti semakin baik kepuasan nasabah bukan berarti tidak berkaitan tetapi tidak selalu meningkatkan loyalitas nasabah. Berdasarkan uraian latar belakang sebelumnya, penting dilakukan riset dengan judul "Pengaruh Kualitas Pelayanan terhadap Loyalitas Nasabah dengan Kepuasan sebagai Variabel Mediasi pada LPD". Adapun tujuan riset ini adalah untuk memperoleh hasil yang teruji mengenai pengaruh, yaitu. (1) kualitas pelayanan pada kepuasan nasabah di LPD Desa Adat Ularan, (2) kualitas pelayanan pada loyalitas nasabah di LPD Desa Adat Ularan, (3) kepuasan nasabah pada loyalitas nasabah di LPD Desa Adat Ularan, (4) kepuasan nasabah memediasi pengaruh kualitas pelayanan pada loyalitas nasabah di LPD Desa Adat Ularan.

Kajian teori yang digunakan dalam riset ini adalah hubungan kepuasan nasabah dalam memediasi dampak kualitas pelayanan pada loyalitas nasabah. Secara tidak langsung kepuasan nasababah mampu memediasi pengaruh kualitas pelayanan terhadap loyalitas 
nasabah (Caruana dalam Iskandar dan Wijaksana, 2015). Tjiptono (2012) menyatakan bahwa kualitas pelayanan selalu berpedoman pada usaha dalam memenuhi seluruh ekspektasi nasabah. Minh dan Huu (2016) menyatakan kualitas layanan dan kepuasan nasabah adalah perantara paling krusial dari kesetiaan nasabah, selain itu kepuasan nasabah memediasi pengaruh kualitas layanan pada loyalitas nasabah. Hal ini sejalan dengan hasil riset yang dilakukan oleh Zakiy dan Azzahroh (2017) yang menunjukkan bahwa secara penuh (full mediation) kepuasan nasabah mampu memediasi pengaruh kualitas layanan pada loyalitas nasabah.

Kualitas pelayanan adalah sikap atau penilaian terhadap pelayanan yang diinginkan nasabah dengan pelayanan yang diterimanya. Pihak LPD perlu memperhatikan kualitas pelayanan dalam upaya memaksimalkan kepuasan nasabahnya. Parasuraman et al. (1988) menyatakan ketika pelayanan yang diberikan mampu melebihi intensi nasabah maka nasabah tersebut merasa senang dan puas. Hubungan kualitas pelayanan terhadap kepuasan nasabah disampaikan oleh Kotler dan Keller (2009) yang menyatakan bahwa nasabah akan merasa puas jika mempersepsikan kualitas layanan yang baik. Hubungan kualitas pelayanan terhadap kepuasan nasabah sejalan dengan hasil riset dari Lee (2013) yang menunjukkan kualitas layanan berdampak positif dan signifikan pada kepuasan nasabah. Hasil riset Trisnayani dan Setiawan (2014) juga menyimpulkan bahwa kualitas layanan berdampak baik dan signifikan pada kepuasan nasabah. $\mathrm{H} 1$ : Terdapat pengaruh kualitas pelayanan pada kepuasan nasabah di LPD Desa Adat Ularan.

Terwujudnya intensi nasabah terhadap berbagai macam pelayanan yang disalurkan LPD akan semakin meningkatkan rasa loyal nasabah terhadap LPD. Rust et al., (1995) dan Zeithaml (2000) dalam Yaqin dan Ilfitriah (2014) menyatakan bahwa kualitas pelayanan bisa memberikan manfaat strategis yang potensial, seperti peningkatan loyalitas nasabah dan peningkatan bank dalam efisiensi operasional kegiatan. Kategori pelayanan yang baik adalah pelayanan yang diberikan kepada nasabah sesuai harapan yang ditandai oleh penanganan service cepat, perlengkapan, pegawai, sarana komunikasi, fasilitas fisik yang memadai, pelayan yang akurat, tanggap, dan memuaskan. Kualitas pelayanan memiliki kaitan erat dengan bank yang menyajikan suatu layanan jasa (Tjiptono, 2012). Teori tersebut sejalan dengan hasil riset Putri dan Suasana (2017) yang menyatakan loyalitas nasabah secara signifikan dipengaruhi oleh kualitas pelayanan. H2: Terdapat pengaruh kualitas pelayanan pada loyalitas nasabah di LPD Desa Adat Ularan.

Posisi LPD yang terus berkembang dan dikenal masyarakat desa merupakan bentuk kepuasan nasabah terhadap layanan LPD, dimana masyarakat akan mulai yakin untuk menabung uangnya di LPD, sehingga distribusi credit LPD semakin tinggi. Kepuasan yang diperoleh nasabah tersebut merupakan inti dari pencapaian profit dalam jangka panjang (Yusnaini, 2010). Adapun operasional kegiatan LPD adalah menyatukan dana dari masyarakat dalam bentuk tabungan, deposito, dan penyaluaran credit hanya kepada masyarakat desa setempat (Yanti et al., 2015). Nasabah yang puas akan semakin loyal dan memberikan proritas utama untuk melakukan transaksi. Hal tersebut sejalan dengan riset dari Lee (2013) yang menunjukkan bahwa kepuasan nasabah tidak hanya memiliki dampak positif pada loyalitas nasabah tetapi juga signifikan. Selain itu, riset yang dilakukan Hidayat (2009) juga menunjukkan hasil yang sama bahwa loyalitas nasabah secara positif dan signifikan dipengaruhi oleh kepuasan nasabah. H3: Terdapat pengaruh kepuasan nasabah pada loyalitas nasabah di LPD Desa Adat Ularan.

LPD harus menempatkan orientasi perhatiannya secara khusus pada pencapaian kepuasan nasabah, yang merupakan kunci utama dalam mempertahankan loyalitas melalui penerapan kualitas pelayanan yang baik. Dalam industri perbankan, kompetisi bank yang ketat dapat meningkatkan suatu profit melalui operasional layanan yang tinggi kepada nasabah (Sabir, 2014). Adanya diferensiasi karakteristik penentuan bank dari nasabah, sehingga perbankan diwajibkan untuk senantiasa meningkatkan layanan dan berinovasi secara konsisten sebagai usaha meningkatkan kepuasan dan loyalitas nasabahnya (Nazarudin dalam Trisnayani dan Setiawan, 2014).

Hubungan kepuasan nasabah dalam memberikan mediasi disampaikan oleh Caruana (2002) dalam Iskandar dan Wijaksana (2015) yang menjelaskan bahwa kualitas pelayanan 
dapat memengaruhi loyalitas nasabah secara tidak langsung dengan dimediasi oleh kepuasan nasabah. Hal tersebut sejalan dengan hasil riset Purnomo dan Widowati (2019) yang menunjukkan kepuasan nasabah dapat memediasi pengaruh variabel kualitas layanan pada loyalitas nasabah, meskipun variabel kualitas layanan secara langsung juga berdampak signifikan terhadap loyalitas nasabah. Berdasarkan riset Putri dan Suasana (2017) juga menegaskan bahwa kepuasan secara signifikan memediasi hubungan antara kualitas layanan pada loyalitas nasabah. H4: Kepuasan nasabah memediasi dampak kualitas pelayanan pada loyalitas nasabah di LPD Desa Adat Ularan.

\section{Metode}

Jenis riset yang digunakan adalah riset kuantitatif. Metode riset kuantitatif merupakan metode riset yang berasaskan pengetahuan dan ilmu yang pasti, digunakan untuk melakukan riset pada populasi atau sample tertentu, menggunakan pengumpulan data, dan bersifat evidensi (kuantitatif) pada analysis data yang telah diatur dengan maksud untuk menyelidiki hypothesis. Desain riset yang digunakan dalam riset ini adalah desain riset kausal. Desain riset kausal adalah riset yang mempunyai tujuan utama untuk menegaskan hubungan timbal balik atau hubungan antara variabel independen dengan variabel yang dependen (Sugiyono, 2014). Suwandi (2012) menjelaskan bahwa tahapan pada riset kuantitatif ada enam, yaitu (1) membuat rumusan masalah, (2) mengkaji landasan teori, (3) menulis hipotesis, (4) menghimpun data, (5) melakukan analisis data, dan (6) membuat simpulan dan saran.

Dalam riset ini menggunakan kualitas pelayanan sebagai variabel independen, kepuasan nasabah sebagai variabel intervening, dan loyalitas nasabah sebagai variabel dependen. Subjek dalam riset ini adalah nasabah tabungan di LPD Desa Adat Ularan. Sedangkan objek pada riset ini yaitu kualitas pelayanan $(X)$, kepuasan nasabah $\left(Y_{1}\right)$, dan loyalitas nasabah $\left(\mathrm{Y}_{2}\right)$. Sampel yang digunakan pada riset ini sejumlah 100 responden. Data dihimpun melalui pencatatan dokumen dan metode kuesioner, serta dianalisis dengan analisis jalur (path analysis). Guna melakukan olah data secara efektif, efisien, dan akurat, maka proses pengolahan data pun dilakukan memakai aplikasi SPSS (Statistical Package for Social Science) tipe 23.0 untuk windows.

\section{Hasil dan Pembahasan}

Hasil dari analisis jalur pengaruh kualitas pelayanan terhadap loyalitas nasabah dengan kepuasan sebagai variabel mediasi pada LPD memakai program SPSS (Statistical Package for Social Science) tipe 23.0 untuk windows diperoleh hasil sebagai berikut.

Tabel 1.

Output SPSS Analisis Jalur

\begin{tabular}{|c|c|c|c|c|c|}
\hline Parameter & Koefisien & $\mathrm{P}$-value & Alpha (a) & Keputusan & Simpulan \\
\hline$R^{2} y_{2} x y_{1}$ & 0,802 & 0,000 & 0,05 & $\begin{array}{l}\text { Menolak } \\
\text { Ho }\end{array}$ & $\begin{array}{lcr}\text { Kualitas pelayanan }(X) & \text { dan } \\
\text { kepuasan nasabah } & \left(\mathrm{Y}_{1}\right) \\
\text { berdampak positif dan } \\
\text { signifikan pada loyalitas } \\
\text { nasabah }\left(\mathrm{Y}_{2}\right)\end{array}$ \\
\hline$P y_{1} x$ & 0,861 & 0,000 & 0,05 & $\begin{array}{l}\text { Menolak } \\
\text { Ho }\end{array}$ & $\begin{array}{l}\text { Kualitas pelayanan }(X) \\
\text { berdampak positif dan } \\
\text { signifikan pada kepuasan } \\
\text { nasabah }\left(Y_{1}\right)\end{array}$ \\
\hline $\mathrm{Py}_{2} \mathrm{X}$ & 0,321 & 0,000 & 0,05 & $\begin{array}{l}\text { Menolak } \\
\text { Ho }\end{array}$ & $\begin{array}{l}\text { Kualitas pelayanan }(X) \\
\text { berdampak positif dan } \\
\text { signifikan pada loyalitas } \\
\text { nasabah }\left(Y_{2}\right)\end{array}$ \\
\hline $\mathrm{Py}_{2} \mathrm{y}_{1}$ & 0,604 & 0,000 & 0,05 & $\begin{array}{l}\text { Menolak } \\
\text { Ho }\end{array}$ & $\begin{array}{lc}\text { Kepuasan } & \text { nasabah } \\
\text { berdampak } & \text { positif }\end{array}$ \\
\hline
\end{tabular}




\begin{tabular}{cccccl}
\hline Parameter & Koefisien & P-value & Alpha $(\alpha)$ & Keputusan & \multicolumn{1}{c}{ Simpulan } \\
\hline & & & & & $\begin{array}{l}\text { signifikan pada loyalitas } \\
\text { nasabah }\left(\mathrm{Y}_{2}\right)\end{array}$ \\
$\mathrm{Py}_{1} \varepsilon_{1}$ & 0,139 & - & - & - & $\begin{array}{l}\text { Besar pengaruh faktor lain } \\
\text { pada kepuasan nasabah }\left(\mathrm{Y}_{1}\right)\end{array}$ \\
$\mathrm{Py}_{2} \varepsilon_{2}$ & 0,198 & - & - & - & $\begin{array}{l}\text { Besar pengaruh faktor lain } \\
\text { pada loyalitas nasabah }\left(\mathrm{Y}_{2}\right)\end{array}$
\end{tabular}

Sumber: Data diolah pada SPSS

Pengaruh masing-masing variabel dapat dilihat pada Gambar 1. berikut.

$\mathrm{H} 2$

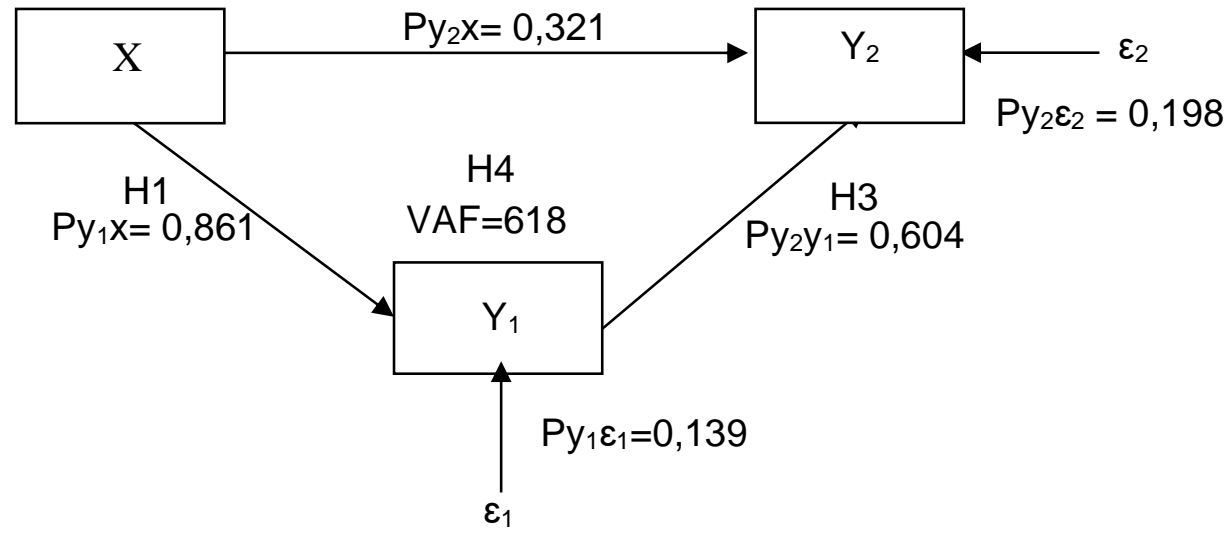

Gambar 1.

Struktur Keseluruhan Pengaruh Kualitas Pelayanan terhadap Loyalitas Nasabah dengan Kepuasan sebagai Variabel Mediasi (Studi pada LPD Desa Adat Ularan, Kecamatan Seririt, Kabupaten Buleleng)

Besar sumbangan pengaruh langsung dan tidak langsung dalam riset ini dapat dilihat pada Tabel 2.

Tabel 2.

Sumbangan Pengaruh Kualitas Pelayanan terhadap Loyalitas Nasabah dengan Kepuasan sebagai Variabel Mediasi (Studi pada LPD Desa Adat Ularan, Kecamatan Seririt, Kabupaten Buleleng)

\begin{tabular}{clll}
\hline No. & Keterangan & Besar & Persentase \\
\hline 1. & Besar pengaruh langsung $X$ terhadap $\mathrm{Y}_{2}$ & 0,321 & $32,1 \%$ \\
2. & Besar pengaruh tidak langsung $\mathrm{X}$ terhadap & 0,520 & $52 \%$ \\
& $\mathrm{Y}_{2}$ melalui $\mathrm{Y}_{1}$ & 0,488 & $48,8 \%$ \\
3. & Besar pengaruh total $\mathrm{X}$ terhadap $\mathrm{Y}_{2}$ & $60,4 \%$ \\
4. & Besar pengaruh langsung $\mathrm{Y}_{1}$ terhadap $\mathrm{Y}_{2}$ & 0,604 & $80,2 \%$ \\
5. & Besar pengaruh total $\mathrm{X}$ dan $\mathrm{Y}_{1}$ terhadap $\mathrm{Y}_{2}$ & 0,802 & $19,8 \%$ \\
6. & Besar pengaruh lain terhadap $\mathrm{Y}_{2}$ & 0,198 & $100 \%$ \\
7. & Total & 1,000 & \\
\hline
\end{tabular}

Hipotesis yang pertama adalah "Terdapat pengaruh kualitas pelayanan pada kepuasan nasabah di LPD Desa Adat Ularan". Dari output perhitungan uji statistik analisis jalur memakai SPSS tipe 23.0 untuk windows, pada Tabel 1. didapat hasil $\mathrm{Py}_{1} \mathrm{x}=0,861$ dengan $p$-value bernilai 0,000 yang lebih rendah dari alpha 0,05 sehingga keputusannya adalah menolak Ho. Ini artinya kepuasan nasabah secara positif dan signifikan dipengaruhi oleh kualitas pelayanan di LPD Desa Adat Ularan dengan besar sumbangan 0,861 atau 
$86,1 \%$. Temuan riset ini menemukan bahwa kualitas pelayanan berperan dalam memengaruhi kepuasan nasabah di LPD Desa Adat Ularan.

Hipotesis yang kedua adalah "Terdapat pengaruh kualitas pelayanan pada loyalitas nasabah di LPD Desa Adat Ularan”. Dari output perhitungan uji statistik analisis jalur memakai SPSS tipe 23.0 untuk windows, pada Tabel 1. didapat hasil $\mathrm{Py}_{2} \mathrm{X}=0,321$ dengan $\mathrm{p}$-value bernilai 0,000 yang lebih rendah dari alpha 0,05 sehingga keputusannya adalah menolak Ho. Ini artinya loyalitas nasabah secara positif dan signifikan dipengaruhi oleh kualitas pelayanan di LPD Desa Adat Ularan dengan besar sumbangan secara total yaitu 0,488 atau $48,8 \%$. Temuan riset ini menemukan bahwa kualitas pelayanan berperan dalam memengaruhi loyalitas nasabah di LPD Desa Adat Ularan.

Hipotesis yang ketiga adalah "Terdapat pengaruh kepuasan nasabah pada loyalitas nasabah di LPD Desa Adat Ularan". Dari output perhitungan uji statistik analisis jalur memakai SPSS tipe 23.0 untuk windows, pada Tabel 1. didapat hasil $\operatorname{Py}_{2} \mathrm{y}_{1}=0,604$ dengan $\mathrm{p}$-value bernilai 0,000 yang lebih rendah dari alpha 0,05 sehingga keputusannya adalah menolak Ho. Ini artinya loyalitas nasabah secara positif dan signifikan dipengaruhi oleh kepuasan nasabah di LPD Desa Adat Ularan dengan besar sumbangan 0,604 atau 60,4\%. Temuan riset ini menemukan bahwa kepuasan nasabah berperan signifikan dalam memengaruhi loyalitas nasabah di LPD Desa Adat Ularan.

Hipotesis yang keempat adalah "Kepuasan nasabah memediasi pengaruh kualitas pelayanan pada loyalitas nasabah di LPD Desa Adat Ularan". Dari output perhitungan uji statistik analisis jalur memakai SPSS tipe 23.0 untuk windows, pada Tabel 1. didapat hasil $\mathrm{Py}_{1} \mathrm{x}=0,861$ dan $\mathrm{Py}_{2} \mathrm{y}_{1}=0,604$. Sumbangan pengaruh tidak langsung didapat dari pengalian $P y_{1} x \cdot P y_{2} y_{1}$ sehingga hasilnya sebesar 0,520 atau $52 \%$. Pengujian mediasi kepuasan nasabah pada dampak kualitas pelayanan pada loyalitas nasabah mengacu Medhika (2018). Dimana uji mediasi dapat dilakukan melalui perhitungan nilai VAF (Variance Accounted For). Untuk menguji apakah kepuasan nasabah mampu memediasi secara total, sebagian (partial) atau tidak dapat memediasi maka nilai VAF inilah yang digunakan. Jika nilai VAF $>80 \%$ maka dapat dikelompokkan dalam mediasi total. Jika nilai VAF 20\% - 80\% maka dapat dikelompokkan dalam mediasi sebagian (partial). Jika nilai VAF $<20 \%$ maka dapat disebut tidak ada mediasi. Dalam perhitungan yang dilakukan, diperoleh hasil nilai VAF dalam pengujian mediasi kepuasan nasabah pada pengaruh kualitas pelayanan ke loyalitas nasabah adalah sebesar 0,618 atau 61,8\%. Berdasarkan ketentuan tersebut dapat disimpulkan bahwa dampak kualitas pelayanan pada loyalitas nasabah dimediasi secara partial oleh kepuasan nasabah. Memediasi parsial artinya variabel kualitas pelayanan mampu memengaruhi secara langsung variabel loyalitas nasabah maupun tidak langsung yang menggunakan mediator variabel kepuasan nasabah.

Hasil riset menegaskan bahwa kepuasan nasabah dipengaruhi oleh kualitas pelayanan secara positif dan signifikan. Ini artinya tinggi rendahnya kualitas pelayanan akan memengaruhi kepuasan nasabah LPD Desa Adat Ularan. Pihak LPD perlu memperhatikan kualitas pelayanan dalam upaya memaksimalkan kepuasan nasabahnya. Pihak LPD harus tetap melakukan pelayanan yang maksimal kepada nasabah. Dalam akses berkomunikasi, pihak LPD menyediakan media dan layanan komunikasi via WA, telepon, dan juga website desa untuk memudahkan nasabah ketika menggunakan jasa LPD. Layanan yang disediakan tersebut didukung oleh kinerja pegawai LPD yang memiliki sikap profesional dalam menghadapi nasabah. Putri dan Suasana (2017) dalam risetnya pada PT. BPD Bali Cabang Renon menyatakan bahwa kualitas layanan berdampak positif signifikan pada kepuasan nasabah. Sehingga, dapat dikatakan meningkatnya kualitas pelayanan dapat meningkatkan kepuasan nasabah.

Hasil riset menegaskan bahwa loyalitas nasabah dipengaruhi oleh kualitas pelayanan secara positif dan signifikan. Ini artinya tinggi rendahnya kualitas pelayanan akan memengaruhi loyalitas nasabah LPD Desa Adat Ularan. Tjiptono (2012) menyatakan bahwa kesetiaan (loyalitas) dapat diciptakan melalui penerapan kualitas pelayanan yang baik. Sejak awal berdiri, mayoritas nasabah memang tetap loyal untuk melakukan transaksi di LPD, walaupun di Desa Adat Ularan juga terdapat BUMdes yang melayani transaksi simpan pinjam. 
Nasabah di LPD Desa Adat Ularan tetap loyal terhadap LPD dan merasa puas atas layanan yang diberikan LPD. Hal ini dikarenakan LPD Desa Adat Ularan memberikan pelayanan yang sudah maksimal. Aturan protokol kesehatan yang disediakan oleh LPD di tengah pandemi covid-19 sangat memadai, seperti tempat cuci tangan, hand sanitizer, dan aturan menjaga jarak di ruang tunggu. Dalam melakukan transaksi ketika menabung, mencari kredit, dan lain sebagainya juga tidak pernah ada permasalahan yang dialami nasabah dengan LPD. Terpenuhinya harapan nasabah terhadap berbagai pelayanan yang diberikan LPD akan semakin meningkatkan rasa loyal nasabah terhadap LPD. Hasil riset Trisnayani dan Setiawan (2014) pada BPD Bali Kantor Cabang Pembantu Kamboja Denpasar menunjukkan hasil yang sama bahwa kualitas layanan juga berdampak positif dan signifikan pada loyalitas nasabah. Sehingga, dapat dikatakan meningkatnya kualitas pelayanan dapat meningkatkan loyalitas nasabah.

Hasil riset menegaskan bahwa loyalitas nasabah dipengaruhi oleh kepuasan nasabah secara positif dan signifikan. Ini artinya tinggi rendahnya kepuasan nasabah akan memengaruhi loyalitas nasabah LPD Desa Adat Ularan. Salah satu kegiatan yang dilaksanakan LPD untuk meningkatkan loyalitas nasabah adalah undian bagi nasabah berupa hadiah hiburan yang berlangsung secara antusias pada saat Rapat Anggota Tahunan (RAT) Desa Adat Ularan. Kegiatan ini ditujukan kepada seluruh nasabah, baik nasabah kredit, penabung, maupun deposito. Undian hadiah ini rutin dilaksanakan setiap tahun pada saat Rapat Anggota Tahunan (RAT) yang disesuaikan dengan perolehan laba yang diperoleh LPD. Jika laba yang diperoleh cukup besar, maka kapasitas hadiah atau undian yang dilakukan bisa lebih luas dan memenuhi harapan nasabah. Hal tersebut dilakukan sebagai ungkapan rasa terimakasih atas dukungan nasabah kepada pihak LPD. Tujuan utamanya tentu agar pengurus LPD tetap mendapat kepercayaan nasabah. Yusnaini (2010) menyatakan bahwa kepuasan yang diperoleh nasabah tersebut merupakan inti dari pencapaian profit dalam jangka panjang, karena nasabah bersikap loyal terhadap LPD. Hal ini sejalan dengan riset Zakiy dan Azzahroh (2017) pada Bank Syariah di Indonesia juga menunjukkan hasil yang sama, bahwa kepuasan nasabah berdampak positif dan signifikan pada loyalitas nasabah. Sehingga, dapat dikatakan meningkatnya kepuasan nasabah dapat meningkatkan loyalitas nasabah.

Hasil riset menunjukkan bahwa kepuasan nasabah memediasi partial pengaruh kualitas pelayanan terhadap loyalitas nasabah. Memediasi partial artinya variabel kualitas pelayanan mampu memengaruhi secara langsung variabel loyalitas nasabah maupun tidak langsung dengan melibatkan mediator variabel kepuasan nasabah LPD Desa Adat Ularan. Sebagai bentuk kepercayaan dan loyalitas dari nasabah, setiap tahunnya LPD Desa Adat Ularan selalu melakukan pembagian atas Sisa Hasil Usaha (SHU) LPD, baik itu untuk keperluan nasabah dan tentunya pembangunan bagi masyarakat Desa Adat Ularan secara umum. Dimana sejumlah 60\% dialokasikan untuk cadangan umum, 20\% dialokasikan untuk dana pembangunan desa adat, $10 \%$ dialokasikan untuk jasa produksi, $5 \%$ dialokasikan untuk dana pembinaan pengawasan dan perlindungan LPD, dan 5\% dialokasikan untuk dana sosial. Berdasarkan riset yang dilakukan Minh dan Huu (2016), menyatakan bahwa kualitas layanan dan kepuasan nasabah adalah perantara paling krusial dari kesetiaan nasabah, selain itu kepuasan nasabah memediasi pengaruh kualitas layanan pada loyalitas nasabah. Sehingga, LPD harus menempatkan orientasi perhatiannya secara khusus pada pencapaian kepuasan nasabah, yang merupakan kunci utama dalam mempertahankan loyalitas melalui penerapan kualitas pelayanan yang baik.

\section{Simpulan dan Saran}

Berdasarkan temuan dan kajian dalam pembahasan tersebut, adapun beberapa simpulan terhadap penelitian, yaitu. (1) kualitas pelayanan berdampak positif dan signifikan pada kepuasan nasabah di LPD Desa Adat Ularan, (2) kualitas pelayanan berdampak positif dan signifikan pada loyalitas nasabah di LPD Desa Adat Ularan, (3) kepuasan nasabah berdampak positif dan signifikan pada loyalitas nasabah di LPD Desa Adat Ularan, (4) kepuasan nasabah memediasi partial dampak kualitas pelayanan pada loyalitas nasabah di LPD Desa Adat Ularan. 
Adapun beberapa saran bagi pihak LPD Desa Adat Ularan diharapkan dapat mempertahankan loyalitas nasabahnya. Tujuan utamanya tentu agar pengurus LPD tetap mendapat kepercayaan nasabah. Sehingga, dengan kepercayaan yang diberikan oleh nasabah, LPD pun dapat berusaha memberikan pelayanan yang sebaik-baiknya guna mempertahankan sikap loyal nasabah dalam jangka panjang.

Bagi peneliti selanjutnya yang berniat untuk melakukan riset mengenai aspek serupa tentang loyalitas nasabah, untuk mengembangkan riset dengan menggunakan variabel reputasi merek, kualitas produk, nilai, dan citra perusahaan. Subjek riset yang berbeda seperti pada BPD Bali atau dapat mengambil subjek riset LPD yang lebih dari satu, serta memperpanjang periode riset agar mendapat hasil yang puspawarna dan dapat mendeskripsikan variabel-variabel yang akan memengaruhi loyalitas nasabah.

\section{Daftar Pustaka}

Dibyantoro, dkk. 2012. "Pengaruh Kualitas Pelayanan Terhadap Kepuasan Nasabah Pada Tabungan BTN Batara. Studi Kasus: PT Bank Tabungan Negara (Persero) Cabang Palembang". Jurnal Ekonomi dan Informasi Akuntansi, Volume 2, Nomor 3 (hlm. 247-259).

Durianto, dkk. 2004. Strategi Menaklukan Pasar Melalui Riset Ekuitas Dan Perilaku Merek (Cetakan Tiga). Jakarta: PT. Gramedia Pustaka Utama.

Ghozali, Imam. 2005. Analisis Multivariat dengan Program SPSS. Semarang : B.P. Universitas Diponegoro Semarang.

Hidayat, Rachmad. 2009. "Pengaruh Kualitas Layanan, Kualitas Produk dan Nilai Nasabah Terhadap Kepuasan dan Loyalitas Nasabah Bank Mandiri". Jurnal Manajemen Dan Kewirausahaan, Volume 11, Nomor 1 (hlm. 59-72).

Iskandar, Dibyo. 2012. "Pengaruh Kualitas Pelayanan Terhadap Loyalitas Nasabah Dengan Kepuasan Dan Kepercayaan Nasabah Sebagai Variabel Intervening (Studi Empiris Nasabah Pd. Bank Perkreditan Rakyat BKK Boyolali Kota". E-Jurnal STIE AUB Surakarta.

Iskandar, Priasmoro dan Tri Indra Wijaksana. 2015. "Pengaruh Kualitas Pelayanan Terhadap Loyalitas Pelanggan Melalui Kepuasan Sebagai Variabel Intervening Pada Pengguna Jasa Transportasi Pt. Tara Megah Muliatama (Taksi Gemah Ripah) Di Kota Bandung". E-Proceeding of Management, Volume 2, Nomor 3 (hlm. 26-38).

Kotler, P., and K. L. Keller. 2012. Marketing Management. New Jersey: Pearson Education, Inc.

Kurniasari, Tri Widya. 2007. "Lembaga Perkreditan Desa (LPD)Dalam Perspektif Hukum : Sebuah Lembaga Keuangan Adat Hindu Penggerak Usaha Sektor Informal Di Bali”. Jurnal Masyarakat dan Budaya, Volume 9, Nomor 1 (hlm. 53-78).

Lee, Hyung Seok. 2013. "Major Moderators Influencing the Relationships of Service Quality, Customer Satisfaction and Customer Loyalty". Asian Social Science, Volume 9, Nomor 2 (hlm. 1-11).

LPD Desa Adat Ularan Tahun 2020.

Medhika, Nyoman Gede Aditya Jay. 2018. "Peran Keunggulan Bersaing dalam Memediasi Orientasi Pasar dan Orientasi Kewirausahaan dengan Kinerja UKM". Jurnal Inovasi Bisnis dan Manajemen Indonesia, Volume 1, Nomor 2 (hlm. 1-18).

Minh, Ngo Vu dan Nguyen Huan Huu. 2016. "The Relationship between Service Quality, Customer Satisfaction and Customer Loyalty: An Investigation in Vietnamese Retail Banking Sector". Journal of Competitiveness, Edisi Khusus (hlm. 103-116).

Octavia, Ria. 2016. Pengaruh Kualitas Pelayanan Dan Kepuasan Nasabah Terhadap Loyalitas Nasabah Tabungan Index Pada PT. Bank Index Kantor Cabang Lampung. 
Tesis (tidak diterbitkan). Program Pascasarjana Magister Manajemen Fakultas Ekonomi dan Bisnis Universitas Lampung Bandar Lampung.

Parasuraman, dkk. 1988. "Serqual A. Multiple item for Measuring Customer Perception of Service Quality". Journal of Retailing, Volume 64, Nomor 1 (hlm. 12-40).

Pemerintah Kabupaten Buleleng Tahun 2019.

Peraturan Daerah (Perda) Provinsi Bali Nomor 3 Tahun 2017.

Permana, I Made Aditya Jaya dan I Ketut Nurcahya. 2014. "Pengaruh Kualitas Pelayanan Terhadap Kepuasan Dan Loyalitas Nasabah Pada LPD Desa Adat Kedonganan". E Jurnal Manajemen Unud, Volume 3, Nomor 7 (hlm. 1830-1849).

Purnomo, Eko dan Retno Widowati. 2019. "Pengaruh Persepsi Nasabah BRI Pada Kualitas Layanan Terhadap Kepuasan Dan Loyalitas Nasabah BRI Kanca Wonosari”. Jurnal Bisnis Teori dan Implementasi, Volume 10, Nomor 1 (hlm. 52-64).

Putri, Desak Ayu Made Marcellina Dewi Giri Putri dan I Gst. A. Kt. Gd. Suasana. 2017. "Peran Kepuasan Dalam Memediasi Pengaruh Kualitas Layanan Terhadap Loyalitas Nasabah". E-Jurnal Manajemen Unud, Volume 6, Nomor 11, (hlm. 6271-6297).

Sabir, dkk. 2014. "Factors Affecting Customer Satisfaction in Banking Sector of Pakistan". International Review of Management and Business Research, Volume 3, Nomor 2 (hlm. 1014-1025).

Sarker, Md. Abdus Salam dan NRM. 2013. "Borhan Uddin. Influence of Service Quality on Customer Satisfaction in Retail Banking: A Study on Some Private Commercial Banks in Bangladesh". Journal Green University Review, Volume 4, Nomor 1-2, (hlm. 68-77).

Selnes, F. 1993. "An Examination of the Effect of Product Performance on Brand Reputation, Satisfaction and Loyalty". European Journal of Marketing. Volume 27, Nomor 9 (hlm. 19-35).

Sembiring, dkk. 2013. Peranan LPD Desa Pakraman Sesetan Terhadap Masyarakat Desa Sesetan. E-Jurnal Agribisnis Dan Agrowisata, Volume 2, Nomor 3 (hlm. 138-145).

Sugiyono, Prof, Dr. 2014. Metode Penelitian Kuantitatif Dan Kualitatif Dan R\&D. Bandung: Alfabeta.

Suwandi, Sarwiji. 2012. Penelitian Tindakan Kelas (PTK) Dan Penulisan Karya Ilmiah. Surakarta: Yuma Pustaka.

Tjiptono, Fandy. 2012. Service Management Mewujudkan Layanan Prima. Yogyakarta: CV Andi Offset.

Trisnayani, I Dewa Ayu Mas Dewi dan Putu Yudi Setiawan. 2014. "Peran Kepuasan Dalam Memediasi Pengaruh Kualitas Layanan Terhadap Loyalitas Nasabah". E-Jurnal Manajemen Unud, Volume 3, Nomor 10 (hlm. 2903-2922).

Wijaya, Ida Bagus Surya dan Kastawan Mandala . 2018. "Pengaruh Kualitas Pelayanan Terhadap Persepsi Nilai Nasabah Yang Dimediasi Oleh Persepsi Risiko". E-Jurnal Manajemen Unud, Volume 7, Nomor 5 (hlm.2652-2679).

Yanti, dkk. 2015. "Pengaruh Dana Pihak Ketiga, Kecukupan Modal, Resiko Kredit Dan Likuiditas Terhadap Profitabilitas LPD Kabupaten Badung". E-jurnal Manajemen Unud, Volume 4, Nomor 12 (hlm. 4362- 4391).

Yaqin, Ainul dan Aniek Maschudah Ilfitriah. 2014. "Pengaruh Kualitas Pelayanan Terhadap Kepuasan Dan Loyalitas Nasabah Bank Pengguna E-Banking Di Surabaya LPD Desa Adat Ularan Tahun 2019". Journal of Business and Banking, Volume 4, Nomor 2 (hlm. 245-260). 
Yusnaini. 2010. "Pengaruh Kualitas Pelayanan Internet Banking Terhadap Kepuasan dan Loyalitas Konsumen pada Bank Swasta". Jurnal Dinamika Akuntansi, Volume 2, Nomor 1 (hlm. 1-9).

Zakiy, Muhammad dan Evrita Putri Azzahroh. 2017. "Pengaruh Kualitas Layanan Terhadap Loyalitas Nasabah Bank Syariah Dengan Kepuasan Nasabah Sebagai Variabel Intervening". Jurnal Ekonomi dan Bisnis Islam, Volume 3, Nomor 1 (hlm. 3953-3959). 